\title{
Laser Cladding Fe-Cr-Si-P Amorphous Coatings on 304L Stainless
}

\author{
Wang Yanfang ${ }^{1,2}, \quad$ Lu Qinglong ${ }^{1}, \quad$ Xiao Lijun ${ }^{1}, \quad$ Shi Zhiqiang ${ }^{1}$ \\ ${ }^{1}$ China University of Petroleum (Huadong), Qingdao 266580, China; ${ }^{2}$ State Key Laboratory of Heavy Oil Processing, China University of Pe- \\ troleum (Huadong), Qingdao 266580, China
}

\begin{abstract}
The Fe-Cr-Si-P amorphous composite coatings were fabricated on 304L stainless steel by laser cladding. The microstructure, the phase composition, the microhardness, the corrosion and wear resistance of the coatings were analyzed by optical microscope (OM), X-ray diffraction (XRD), scanning electron microscopy (SEM), a microhardness tester, an electrochemical measurement system and a friction and wear tester. The results show that the cladding coating mainly contains plum-like dendrite crystals in the surface, an amorphous in center region and a dendrite crystals in binding zone. A good metallurgical bond is obtained between the coating and substrate. Except amorphous phase, the cladding coating contains a small amount of $\mathrm{Fe}_{3} \mathrm{P}$ and $\mathrm{Fe}_{2} \mathrm{Si}$ phases. The coating has a good performance. The microhardness $\mathrm{HV}_{0.2}$ is about $8000 \mathrm{MPa}$; the $E_{\text {corr }}$ and $i_{\text {corr }}$ are $-449.3 \mathrm{mV}$ and $4.34 \mu \mathrm{A} / \mathrm{cm}^{2}$, respectively; the frictions coefficient at the load of $100 \mathrm{~N}$ is 0.076
\end{abstract}

Key words: laser cladding; amorphous coating; Fe-Cr-Si-P alloy; microstructure; properties

Fe-based bulk metallic glasses (BMGs) have promising application prospects due to their high abundant natural resources, relatively low material cost, and unique physical and mechanical properties, such as high hardness, superior corrosion and wear resistance ${ }^{[1-4]}$. However, the applications of these amorphous alloys have been restricted for the small size. BMG coatings have the potential to be extensively used in the industrial environments. Thermal spray and plasma spray technologies have been used to fabricate amorphous coatings. The microstructure and various properties of Fe-based amorphous coatings prepared by high velocity oxygen fuel (HVOF), high velocity air fuel (HVAF) spray or plasma spray processes are been studied ${ }^{[5-8]}$.

Laser cladding is also an effective way to obtain amorphous coatings on metallic substrates due to the sufficiently rapid heating and cooling which inhibit long-range diffusion and prevent crystallization ${ }^{[9]}$. Since Yoshioka first reported the laser cladding amorphous coating in $1987^{[10]}$, various amorphous alloys have been cladded on different metallic substrates.
Wong et $\mathrm{al}^{[11]}$ cladded a Ni-Cr-B-Si alloy on a Al alloy substrate. They found that the amorphous phase in the coating contributes to surface hardening and tribological properties. Wang $^{[12]}$, Yue ${ }^{[13]}$ and Huang ${ }^{[14]}$ cladded $\mathrm{Cu}-\mathrm{Zr}-\mathrm{Al}$ or $\mathrm{Zr}$-Al-Ni-Cu amorphous coatings on $\mathrm{Mg}$ substrate to improve the tribological and corrosion properties. $\mathrm{Wu}^{[15]}$, Basu ${ }^{[16]}$ and $\mathrm{Zhu}^{[17]}$ cladded Fe-based alloys on steel substrate. We have cladded a Zr-based alloy on Ti substrate and got a coating consist of a mixture of intermetallic compound, including a nanocrystalline phase and an amorphous phase ${ }^{[18,19]}$.

In the present work, Fe-Cr-Si-P amorphous powders were laser-claded on a 304L stainless. The microstructure, the phase and composition, the microhardness, the tribological and the corrosion properties of the coating were studied.

\section{Experiment}

The specimens of 304L stainless steel with size of $30 \mathrm{~mm} \times 20$ $\mathrm{mm} \times 10 \mathrm{~mm}$ were used as substrates. Their surfaces were machined to a uniform finish, and then cleaned by acetone and al-

Received date: March 25, 2013

Foundation item: "863" Project (2012AA09A203); Nature Science Founding of Shandong Province (Q2008F12); Fundamental Research Funds for the Central Universities (11CX04032A, 11CX06069A)

Corresponding author: Wang Yanfang, Ph.D., Associate Professor, Department of Materials Science and Engineering, China University of Petroleum (Huadong), Qingdao 266580, P. R. China, Tel: 0086-532-86983503-8504, E-mail: wang@upc.edu.cn 
cohol just before the laser-clad. The Fe-based amorphous powder was selected for the foundation cladding materials. The nominal composition of the alloy was $\mathrm{Fe}_{64.7} \mathrm{Cr}_{19.2} \mathrm{Si}_{2.0} \mathrm{P}_{14.1}$.

The powders were pre-placed onto the specimen surfaces homogeneously. The thicknesses of the pre-placed coatings were about $1 \mathrm{~mm}$. The coatings were cladded by DL-HL-T5000 $5 \mathrm{~kW}$ continuous $\mathrm{CO}_{2}$ laser processing equipment. The values of laser power, the scanning speed and the laser beam size were $3.6 \mathrm{~kW}, 400 \mathrm{~mm} / \mathrm{min}$, and $1 \mathrm{~mm} \times 10 \mathrm{~mm}$, respectively. Argon was served as a protective gas to avoid the oxidation of alloy powder during the cladding.

$\mathrm{X}$-ray diffractometry (XRD) was carried out for phase identification with $\mathrm{Cu} \mathrm{K} \alpha$ irradiation $(\lambda=0.154060 \mathrm{~nm}$ ). The microstructure of the coating was characterized with optical microscopy (OM) and scanning electron microscopy (SEM) equipped with an energy dispersive spectrometer (EDS), which was used for the composition analysis of the clad layer.

The cross-section microhardness of the cladding layer was measured by a HV-100A type hardness meter with a load of 200 $\mathrm{g}$, employing a loading time of $15 \mathrm{~s}$. Dry sliding wear tests were performed with a MMU-5 type pin-on-disk wear testing machine. A GCr15 (HRC 63) pin was selected as the counterparts. The experimental parameters were: applied load $100 \mathrm{~N}$, sliding speed $100 \mathrm{r} / \mathrm{min}$, sliding $60 \mathrm{~min}$. The friction coefficient was continuously recorded during the test. The corrosion behaviors of laser-clad coatings were evaluated by electrochemical polarization measurements. Prior to tests, the specimens were mechanically polished to mirror finish, and then degreased in acetone, washed in distilled water and dried in air. Electrochemical measurements were conducted in a three-electrode cell using a platinum counter electrode and a standard saturated calomel reference electrode (S.C.E.). The specimens for the corrosion test were closely sealed with epoxy resin, leaving only about $1 \mathrm{~cm}^{2}$ surface exposed for testing. Electrochemical polarization curves were recorded at a potential sweep rate of $0.166 \mathrm{mV} / \mathrm{s}$ after immersing the specimens for about $20 \mathrm{~min}$ when the open circuit potentials became almost steady.

\section{Results and Discussion}

\subsection{Microstructure of the laser cladding coatings}

The microstructure of $\mathrm{Fe}_{64.7} \mathrm{Cr}_{19.2} \mathrm{Si}_{2.0} \mathrm{P}_{14.1}$ laser cladding coating is shown in Fig.1. Fig.1-1 shows the cross-section image of the laser cladding Fe-based amorphous coating. Three regions are obviously observed: coatings, bonding zone and substrate. The substrate is typical austenitic stainless (Fig.1-5). The maximum thickness is approximately $1 \mathrm{~mm}$. No cracks and voids are observed within the coating. Fig.1-2 1-5 are magnification images of A, B, C and D zone in Fig.1-1. The laser clad region of experienced different temperature gradients and cooling rates during solidification at different distances from the substrate, presents various morphologies. In regions near the interface with the substrate (Fig.1-4), the temperature gradient and the quenching rate are high, and the

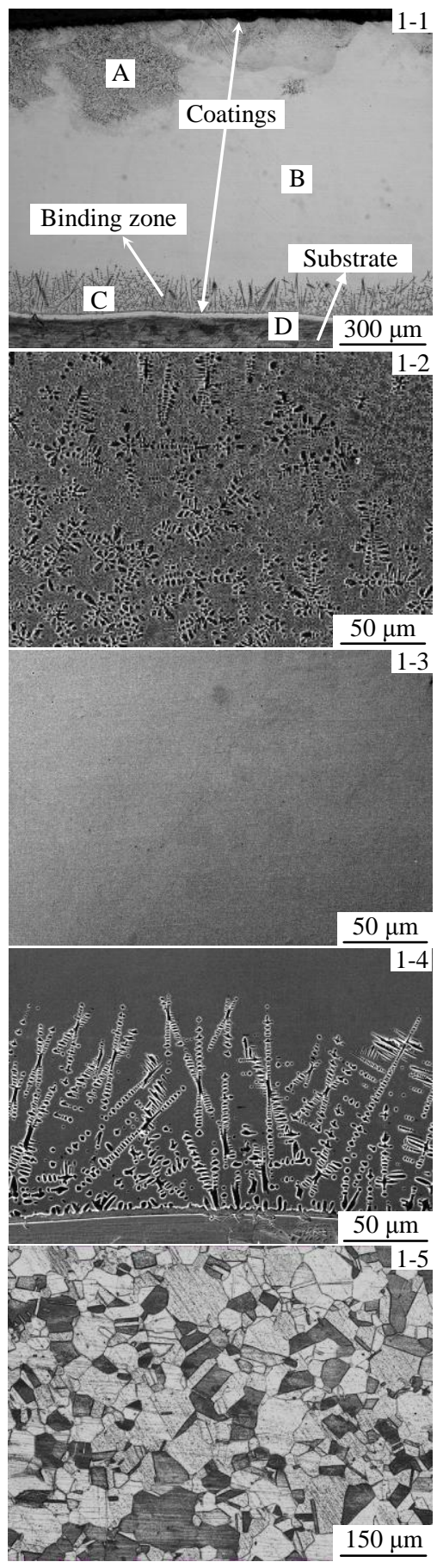

Fig.1 Microstructure of laser cladding coating 1-1: morphology of clad zone, 1-2 5: magnification of A, B, C and D zone in Fig.1-1

solidification progressed in a planar front. As a results, the microstructure exhibits columnar crystalline solidification morphology. And then, the crystalline will growth directionality along the direction of maximum heat dissipation. Therefore, the epitaxial growth characters of dendrites are formed in this region. In the middle of the coating, the dendritic crystalline would be restrained and then sudden interrupted. A lager area 
of amorphous zone is formed in this region (Fig.1-3). The surface of the coating is the last solidification region, due to the alloy composition and the solidification condition changing, a dendritic crystalline appears in this region. Different from the bonding zone, the dendritic crystalline lost its heat dissipation direction obviously, the dendritic crystalline is showing "plum" shape (Fig.1-2). EDS analysis shows that the composition of the dendritic crystalline is $\mathrm{Fe}_{77.89} \mathrm{Cr}_{13.96} \mathrm{Si}_{3.54} \mathrm{P}_{4.61}$, between dendritic crystalline is $\mathrm{Fe}_{49.88} \mathrm{Cr}_{30.18} \mathrm{P}_{19.94}$. The composition of the middle zone is $\mathrm{Fe}_{55.02} \mathrm{Cr}_{24.91} \mathrm{Si}_{1.15} \mathrm{P}_{18.92}$, which is similar to the composition of the primal alloy powder $\mathrm{Fe}_{64.7} \mathrm{Cr}_{19.2} \mathrm{Si}_{2.0} \mathrm{P}_{14.1}$.

Fig. 2 shows the $\mathrm{X}$-ray diffraction patterns of the laser clad coating and the raw powder. Only a broad diffraction peak appearing within $2 \theta=40^{\circ} \sim 50^{\circ}$ indicates the fully amorphous phase of the laser clad powder. Except the broad diffraction peak, several sharp peaks corresponding to crystalline phase are also presented in the XRD pattern of the coating. Indexing of these diffraction peaks reveals that the peaks are those of $\mathrm{Fe}_{3} \mathrm{P}$ and $\mathrm{Fe}_{2} \mathrm{Si}$ phases. This pattern indicates that the sample mainly consists of amorphous and $\mathrm{Fe}_{3} \mathrm{P}, \mathrm{Fe}_{2} \mathrm{Si}$ crystalline phases. About $47 \%$ amorphous phase in volume is estimated from the area of the broad peak by Pseudo-Voigt function fitting in the coating.

\subsection{Properties of the laser cladding coating}

Fig. 3 shows the microhardness profile along the depth of the coating. It is seen that the microhardness of the coating is very uniform. The microhardness of the coating is about 4 times higher than that of 304L stainless substrate.

Fig. 4 shows the variation of the friction coefficient with the sliding times of the laser cladding $\mathrm{Fe}-\mathrm{Cr}$-Si-P coating and 304L stainless substrate. It can be seen that the friction coefficient of the laser cladded coating is very small, only 0.076 within the sliding time. It is much lower than that of the 304L stainless substrate. This pattern indicates that the laser cladding $\mathrm{Fe}-\mathrm{Cr}-\mathrm{Si}-\mathrm{P}$ coating containing amorphous phase has a good lubrication property.

Fig.5 shows the electrochemical polarization curves of the laser cladding $\mathrm{Fe}-\mathrm{Cr}-\mathrm{Si}-\mathrm{P}$ coating and the 304L stainless

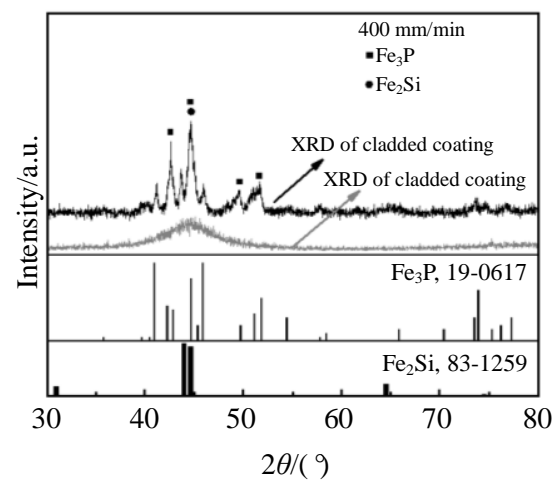

Fig.2 XRD patterns of laser cladding Fe-Cr-Si-P coating and raw powder

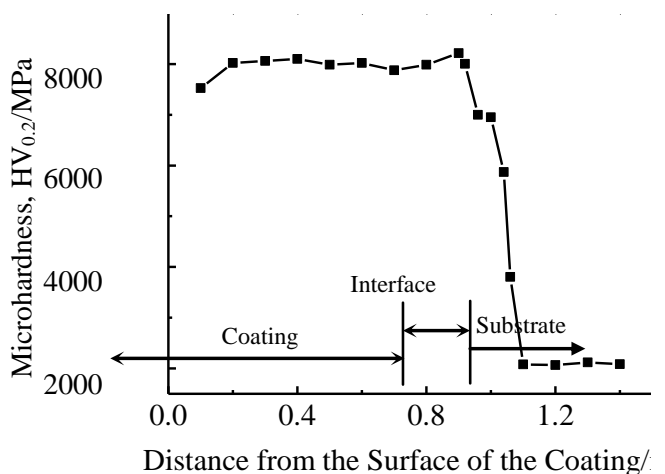

Fig.3 Microhardness cross-section distribution of the coating

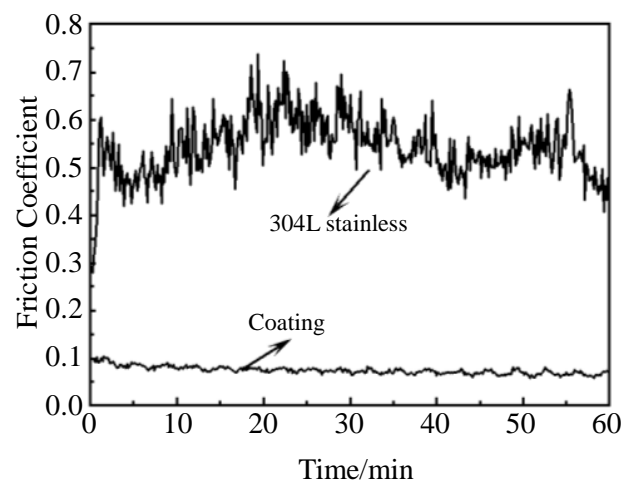

Fig.4 Friction coefficient curves of the laser cladding Fe-Cr-Si-P coating and $304 \mathrm{~L}$ substrate at $100 \mathrm{~N}$

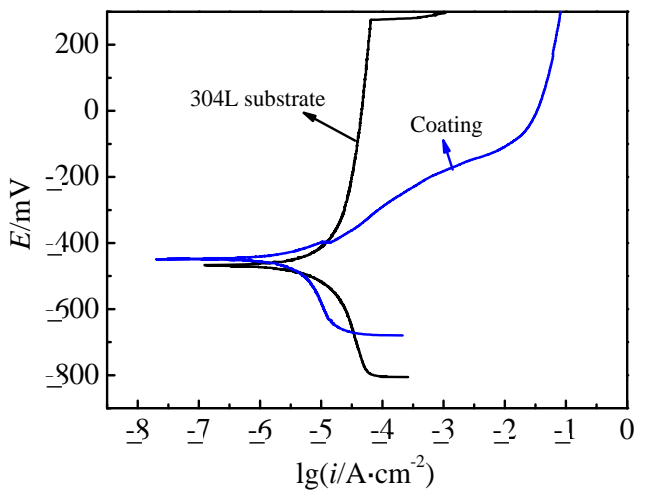

Fig.5 Polarization curves of the laser cladding Fe-Cr-Si-P coating and 304L substrate

substrate in $3.5 \mathrm{wt} \% \mathrm{NaCl}$ solutions. The 304L stainless exhibits passivation, but no obvious passivation appears in the coating. The corrosion potential $\left(E_{\text {corr, }} \mathrm{mV}\right)$ and corrosion current density $\left(I_{\text {corr }}, \mathrm{A} / \mathrm{cm}^{2}\right)$ got from the polarization curves are listed in Table 1. It can be seen that the corrosion potential of the coating and 304L substrate has a close value. However, the corrosion current density of the coating is much lower than that of the substrate, indicating that the coating has better corrosion resistance than the 304L stainless. The amorphous phase existing in the coating may contribute to the good corrosion resistance. 
Table 1 Corrosion potential and corrosion current density of the coating and the 304L substrate

\begin{tabular}{ccc}
\hline Sample & $E_{\text {corr }} / \mathrm{mV}$ & $i_{\text {corr }} / \mu \mathrm{A} \cdot \mathrm{cm}^{-2}$ \\
\hline Coating & -449.3 & 4.34 \\
304L substrate & -468.1 & 11.22 \\
\hline
\end{tabular}

\section{Conclusions}

1) The Fe-Cr-Si-P amorphous powders have been laser-clad on 304L stainless substrates. The coating consists of a mixture of amorphous phase and $\mathrm{Fe}_{2} \mathrm{Si}, \mathrm{Fe}_{3} \mathrm{P}$ crystalline phases. The typical microstructures are plum-like dendrite crystals in the surface, amorphous in center region and dendrite crystals in binding zone.

2) The coating shows higher microhardness, lower friction coefficient and better corrosion resistance compared to that of the $304 \mathrm{~L}$ stainless substrate.

\section{References}

1 Justin Cheney, Kenneth Vecchio. Materials Science and Engineering $A[\mathrm{~J}], 2008,492: 230$

2 Qiu K Q, Pang J, Ren Y L et al. Materials Science and Engineering $A[\mathrm{~J}], 2008,498: 464$

3 Pan Jie, Chen Qi, Li Ning et al. Journal of Alloys and Compounds[J], 2008, 463: 246

4 Jarosław Ferenc, Tatiana Erenc-Sedziak, Maciej Kowalczyk et al. Journal of Alloys and Compounds[J], 2010, 495: 327

5 Krishnarao Venugopal, Manish Agrawal. Wear[J], 2008, 264:
139

6 Cheng Jiangbo, Liang Xiubing, Xu Binshi et al. Journal of Non-Crystalline Solids[J], 2009, 355: 1673

7 Guo R Q, Zhang C, Chen Q et al. Corrosion Science[J], 2009, 355: 1673

8 Yao Chengwu, Huang Jian, Zhang Peilei et al. Applied Surface Science[J], 2011, 257: 2184

9 Yang Yongqiang, Song Yonglun, Wu Weitao et al. Thin Solid Films[J], 1998, 323: 199

10 Yoshioka H, Asami K, Kawashima A et al. Corrosion Science[J], 1987, 27: 981

11 Wong T T, Liang G Y, He B L et al. Journal of Materials Processing Technology [J], 2000, 100: 142

12 Liu H B, Wang C S, Gao Y L et al. Chinese Journal of Lasers[J], 2006, 33: 709

13 Yue T M, Su Y P. Applied Surface Science[J], 2008, 255: 1692

14 Huang K J, Lin X, Chen C et al. Chinese Journal of Lasers[J], 2007, 34: 549

$15 \mathrm{Wu}$ X L, Hong Y S. Surface and Coatings Technology[J], 2001, 141: 141

16 Basu A, Samant A N, Harimkar S P et al. Surface and Coatings Technology[J], 2008, 202: 2623

17 Zhu Qingjun, Qu Shiyao, Wang Xinhong et al. Applied Surface Science[J], 2007, 253: 7060

18 Wang Y F, Li G, Wang C S et al. Surface and Coatings Technology[J], 2004, 176: 284

19 Wang Y F, Li L, Lu Q L et al. Chinese Journal of Lasers[J], 2011, 38: 0603017

\title{
304L 不锈钢表面激光熔覆 Fe-Cr-Si-P 非晶涂层
}

\author{
王彦芳 ${ }^{1,2}$, 鲁青龙 ${ }^{1}$, 肖丽君 ${ }^{1}$, 石志强 ${ }^{1}$ \\ (1. 中国石油大学 (华东), 山东 青岛 266580) \\ (2. 中国石油大学 重质油国家重点实验室, 山东 青岛 266580)
}

\begin{abstract}
摘 要: 采用激光熔覆技术在 $304 \mathrm{~L}$ 不锈钢基体表面制备了Fe-Cr-Si-P非晶复合涂层。利用光学显微镜（OM）、X射线衍射仪（XRD）、 扫描电子显微镜 (SEM)、电化学测试系统和摩擦磨损试验机等分析了涂层的组织结构、相组成、耐蚀及耐磨等性能。研究结果表明, 激光熔覆层组织主要由表层 “梅花” 形树枝晶区, 中心非晶区和树枝晶结合区组成, 熔覆层与基体呈现良好的冶金结合。熔覆层中除了 非晶相外，还有少量 $\mathrm{Fe}_{3} \mathrm{P}$ 和 $\mathrm{Fe}_{2} \mathrm{Si}$ 等金属间化合物相。涂层的硬度 $\mathrm{HV}_{0.2}$ 约为 $8000 \mathrm{MPa}$, 是基体硬度的4倍; 腐蚀电位 $E_{\mathrm{corr}}$ 和自腐蚀电流密 度 $i_{\text {corr }}$ 分别为 $-449.3 \mathrm{mV}$ 和 $-4.34 \mu \mathrm{A} / \mathrm{cm}^{2}$; 在 $100 \mathrm{~N}$ 载荷下摩擦系数仅为 0.076 , 具有较好的综合性能。
\end{abstract}

关键词: 激光熔覆; 非晶涂层; Fe-Cr-Si-P; 组织; 性能

作者简介: 王彦芳, 男, 1976 年生, 博士, 副教授, 中国石油大学(华东)材料科学与工程系, 山东 青岛 266580, 电话: 0532-86983503-8504, E-mail: wang@upc.edu.cn 